\title{
Reflections on how librarians teach information literacy
}

A book review of Aston, S. and Walsh, A. (eds.) (2021) Library Pedagogies: Personal reflections from library practitioners. Huddersfield: Innovative Libraries Press.

\author{
Michelle Breen \\ University of Limerick
}

Keywords: Library instruction; information literacy; teaching; pedagogies.

\section{Overview}

This book will help librarians to reflect on and improve their teaching to meet the contemporary needs of their learners and develop the information and digital skills of students. Librarians who teach don't need reminding of the many definitions that exist for information literacy from ALA, ANCIL and CILIP as examples. Equally important in current library instruction is the JISC definition of digital literacy: "equipping students to live, learn and work in a digital society" (JISC, 2019).

As information literacy instruction does, the contributions in this book transcend subject discipline. Rather than prescribing one single 'best' way of teaching, the book presents a range of pedagogical approaches, giving librarians a menu of options to experiment with to suit them, their topic, their institution and its learners. This book has practical advice on how to help students learn new skills from library instructional sessions.

\section{Structure and Content}

With contributions from 22 authors, plus the editors, the book examines library pedagogies through many lenses. With this volume of varied contributions, the editors divided the book into sections. The chapters are grouped around the themes of information literacy, authority and power, and pedagogies that have been influenced 
by specific contexts and environments. As practitioners for whom time is increasingly scarce, librarians may find it useful to begin by reading the author profiles to identify chapters of most relevance to their own context. The editors have compiled a useful handbook that librarians can dip in to regularly to broaden their perspective on effective pedagogical approaches to teaching information literacy.

The book has many well observed anecdotes from classroom experiences. The examples serve to highlight the limitations of approaches such as EDIP (Explain, Demonstrate, Inquire, Practice) for student learning. Telling students things, and giving them the answers, as vividly described in Emma Coonan's honest recollection on her 'beautifully designed, cut and dried prepared searches' (Coonan, 2021, p. 45) that she had used in her classes with students is less effective than an engaged dialogue with your students about what they need. Emma's personal pedagogical approach of "listening to and working with my class participants showed me that exploring a topic from multiple perspectives rather than trying to 'fix' it immediately could help students better understand the complexities of learning and research" (Coonan, 2021, p.56). As you read this book, take time to consider this: if students can interrogate the library catalogue and databases at the end of an instructional session with you, have they learnt anything? Are we satisfied with this surface learning as described by Wotherspoon (p. 378) or do librarians want students to experience deeper and more meaningful learning in library classes?

The value of reflecting on your teaching is a recurring theme throughout the book. Sound pedagogical approaches underpin successful teaching. The chapter authors honestly share their experiences and describe an openness to experimentation and discovery in their teaching that makes this book a must read for any librarians who teach.

\section{Final Thoughts}

The takeaways for me from the book are that information literacy teaching needs to be designed to create learner autonomy. Heather Barker describes how she adjusted standard lesson plans to "incorporate activities where choice of search terms and resources were left to the learner" (Barker, 2021, p. 19) thereby transferring ownership of learning to learners. This approach to teaching and skills building will 
give students the methods and approaches needed to become confident in their ability to find, use and manage information. Librarians need to take a step back from their teaching at intervals to reflect on how they teach and what techniques they can apply to support student learning. Aston and Walsh have assembled a useful reference text for librarians, and I envisage a relevance for the book in our professional dialogue, helping libraries to review their current approaches to teaching information literacy.

I commend the editors for including this line in their preface and I would hope that this practice becomes widespread across new books, encouraging a move towards a more open approach to published content:

"Individual chapters may be copied or scanned for educational purposes, for permission to scan/copy more than a chapter or to host a PDF version of this work for educational purposes such as a reading list or course pack, please contact the editors".

\section{Reference list}

ALA (American Library Association) (2015) Framework for Information Literacy for Higher Education. Available at: http://www.ala.org/acrl/standards/ilframework (Accessed 14 March 2021).

Aston, S. and Walsh, A. (eds.) (2021) Library Pedagogies: Personal reflections from library practitioners. Huddersfield: Innovative Libraries Press.

Barker, H. (2021) 'Developing the Learner Librarian: Traversing threads, thresholds and transformations' in Aston, S. and Walsh, A. (eds.) 2021. Library Pedagogies: Personal reflections from library practitioners. Huddersfield: Innovative Libraries Press.

CILIP (2018) CILIP Definition of Information Literacy, Available at: https://infolit.org.uk/ILdefinitionCILIP2018.pdf (Accessed 14 March 2021). 
Coonan, E. (2021) 'Librarian through the looking-glass: Developing a teaching philosophy on shifting ground', in Aston, S. and Walsh, A. (eds.) (2021) Library Pedagogies: Personal reflections from library practitioners. Huddersfield: Innovative Libraries Press.

JISC (2019) JISC Digital Capabilities Framework: the six elements defined. Available at: https://repository.jisc.ac.uk/7278/1/BDCP-DC-Framework-Individual-6E-110319.pdf (Accessed 14 March 2021).

Wotherspoon, E. (2021) 'Digital Literacy in a post-Covid world: e-pedagogical approaches to develop social, academic and employability skills' in Aston, S. and Walsh, A. (eds.) (2021) Library Pedagogies: Personal reflections from library practitioners. Huddersfield: Innovative Libraries Press.

\section{Author Details}

Michelle Breen is the Head of the Information Services Department at the Glucksman Library at the University of Limerick. Michelle's department supports the learning, teaching and research needs of the university community through their work on collections, in teaching, and the provision of reference and consultation services. Michelle has worked in academic libraries since 2006, beginning in faculty liaison work and subsequently held a variety of roles in the library. Michelle's department moved to online teaching in March 2020 and has offered experimental digital skills workshops to students at the University of Limerick, alongside more traditional instructional sessions, always striving to achieve best practice in the physical or virtual classroom that matches the session's learning outcomes. Michelle has published in peer-reviewed journals and practitioner literature, presented at many conferences and is a member of Ireland's LAI Council and an active member of CONUL's Communications and Outreach group. 